\title{
STAT5B/RARA Fusion Gene
}

National Cancer Institute

\section{Source}

National Cancer Institute. STAT5B/RARA Fusion Gene. NCI Thesaurus. Code C99666.

A fusion gene that results from a complex rearrangement of $17 q 21$ that fuses the $5^{\prime}$ portion of the STAT 5B gene to exon 3 of the RARA gene. This chromosomal aberration may be associated with acute promyelocytic leukemia. 